Turkish Online Journal of Qualitative Inquiry (TOJQI)

Volume 11, Issue 4, October 2020: 481-510

DOI: $10.17569 /$ tojqi.723172

Research Article

\title{
Analysis of Some of the Primary Education Curricula in Terms of International Social and Emotional Skills ${ }^{1}$
}

\author{
E. Seda Koç²
}

\begin{abstract}
Social and emotional skills are the basic competencies required for individuals, who are a social creature, to continue their development in a healthy and desired way. In this study, it is aimed to analyze the curricula that are responsible for the formal acquisition of these competencies. In the study, Turkish, life studies, social studies, science and mathematics curricula at primary education level were examined in terms of international social and emotional skills. The study, which is an example of qualitative research, was conducted according to the case study model. In the analysis of the curricula, the international social and emotional skills determined by the OECD were considered as criteria and document analysis technique was used. According to the findings obtained in the study, it was determined that the majority of these skills were included in the curricula, but the attainment rate associated with these skills was not sufficient. It was also concluded that the belief in success, stress resistance, trust, and curiosity were skills that were not included in any of the curricula. Another important deficiency determined in the study is that none of the social and emotional skills were included in the mathematics curriculum.
\end{abstract}

Keywords: Curriculum, skill, social and emotional skills

\footnotetext{
${ }^{1}$ The ethical committee permission is not required in this study since the data were gathered through document analysis.

${ }^{2}$ Assist.Prof. Dr, Namık Kemal University, Vocational School of Health Sciences, Child Development Department eskoc@nku.edu.tr, https://orcid.org/0000-0003-1656-8808
}

Received: 19.04.2020, Accepted: 21.09.2020 


\title{
Bazı İlkokul Öğretim Programlarının Uluslararası Sosyal ve Duygusal Beceriler Açısından İncelenmesi
}

\begin{abstract}
Öz
Sosyal ve duygusal beceriler sosyal bir canlı olan bireylerin gelişimlerini sağlıklı ve istendik yönde sürdürebilmeleri için gerekli olan temel yeterliklerdir. $\mathrm{Bu}$ çalışmada söz konusu yeterliklerin formal kapsamda kazandırılmasından sorumlu olan öğretim programlarının analiz edilmesi amaçlanmıştır. Çalışmada ilkokul Türkçe, hayat bilgisi, sosyal bilgiler, fen ve matematik dersi öğretim programları uluslararası sosyal ve duygusal beceriler açısından incelenmiştir. Bir nitel araştırma örneği olan çalışma durum çalışması modeline göre yürütülmüştür. Çalışmada öğretim programlarının analizinde OECD tarafından belirlenmiş olan uluslararası sosyal ve duygusal beceriler ölçüt alınmış olup doküman incelemesi tekniği kullanılmıştır. Çalışmada elde edilen bulgulara göre söz konusu becerilerden büyük bir çoğunluğuna programlarda yer verilmiş olduğu ancak söz konusu becerilerle ilişkili kazanım oranının yeterli düzeyde olmadığı belirlenmiştir. Başarma inancı, strese dayanıklılık, güven, merak becerilerinin öğretim programlarının hiçbirinde yer verilmemiş olan beceriler olduğu sonucuna ulaşılmıştır. Çalışmada belirlenmiş olan bir diğer önemli eksiklik ise matematik öğretim programında sosyal ve duygusal becerilerden hiçbirine yer verilmemiş oluşudur.
\end{abstract}

Anahtar Sözcükler: Öğretim programı, beceri, sosyal ve duygusal beceri 


\section{Introduction}

Curricula are life arrangements that contain all the activities of a discipline that are aimed to be gained by individuals (Demirel, 2007). The main elements in these life arrangements consist of the attainments/objectives that express the learning outcomes; the content elements that meet the scope of learning in other words the learning areas and the topics related to the course; the teaching experiences that indicate how learning will be carried out, and the assessment-evaluation situations that asses all these elements. Apart from these basic elements, to make the curriculum more comprehensive and qualified, it is possible to include the values, skills, and concepts expected in the related course in the curricula (Çoban \& Akşit, 2018). To achieve the objectives of the curricula, all of the mentioned items can fulfill their duties and functions completely (Özkan, 2009); also these items must be compatible with each other.

Attainments, which are the first of the basic elements in the curriculum, are the expressions that describe the knowledge, skills, and competencies of the cognitive, affective and psychomotor areas that we can call the dimensions of learning, which students are expected to have at the end of a unit, term or academic year (ERG, 2012). The two important reference points that are taken into account when determining these achievements are the needs of the individual and society. The rapid change in the world changes these needs at the same speed and accordingly, it is an increasing effort that the attainments in the curricula can be arranged to meet these needs. For this reason, today, It is aimed to reflect the skills that students will need in their personal, social, academic and business life to the curriculum at both national and international levels (MEB, 2018).

Skills are defined as the abilities designed to be acquired, developed and transferred to students in the learning process (Narin, 2007). Through these skills, students are expected to achieve attainments that they will earn and use throughout their life vertically at the end of a year and horizontally at the end of the curriculum in connection with their development in learning areas (Özatalay, 2007). The acquisition of skills takes place at the end of a process. Knowledge must first be obtained. While learning takes place, skills should be gained, developed and transferred to life (Hezen, 2009). 
Skill consists of three components: knowledge, practice knowledge and making work. These components can be summarized as follows;

1. Knowledge includes information about the job (task) to do.

2. Practise involves knowing about work (task), knowledge, and mobilizing mental resources. All mental and physical resources must be mobilized to take action.

3. Making work is realizing the task by mobilizing all physical and mental resources. During the work, the psychological and social status of the individual is important (Dionnet, 2002).

Nowadays, skills are given more place in the curriculum and attention is paid to ensure that all curriculum elements, especially the attainments, reflect these skills. Skills included in the curriculum can be skills specific to the subject in question, as well as common basic skills required by individuals who are common to all lessons. It is possible to define basic skills as competencies that individuals need to acquire through formal education. These skills are accepted as the basic conditions for the human model desired to be in the 21 st century (Altunbay, 2015). For this reason, it is important to include all basic skills adequately in the curriculum in terms of individual achievements and social cohesion of people in their future lives.

Various studies are carried out to determine the skills expected to take place in the curriculum and different criteria emerge as a result of these studies. By the Ministry of Education, through the Turkey Qualifications Framework eight key competencies were identified for the skills take part in the curricula developed after 2018. These competencies, which are common to all of the curricula, are included in the curricula together with their descriptions and it is tried to be clarified which skills can be gained within the scope of competence. These competencies are as follows;

1. Communication in the mother language,

2. Communication in foreign languages,

3. Mathematical competence and basic competencies in science/technology,

4. Digital competence,

5. Learning to learn,

6. Social and citizenship competencies,

7. Taking initiative and entrepreneurship, 
8. Cultural awareness and expression (MEB, 2018).

In some of the curricula, apart from these competencies, course-specific skills are also included. In the curriculum of life sciences, 23 skills and in the curriculum of social sciences 27 skills were included. 6 of these skills are common. The skills in the curricula are as follows;

Table 1

Skills in life sciences and social studies curriculum

\begin{tabular}{|c|c|c|}
\hline Life Sciences Curriculum Skills & Common Skills & Social Sciences Curriculum Skills \\
\hline $\begin{array}{l}\text { Information and communication, } \\
\text { using technologies, balanced } \\
\text { nutrition, protection of nature, } \\
\text { observation, communication, career } \\
\text { awareness, use of resources, self- } \\
\text { protection, self-knowledge, } \\
\text { personal care, compliance with } \\
\text { rules, recognition of national and } \\
\text { cultural values, self-management, } \\
\text { health protection, problem-solving, } \\
\text { social participation, time } \\
\text { management. }\end{array}$ & $\begin{array}{l}\text { Research, Perception of } \\
\text { space, perceiving } \\
\text { change and continuity, } \\
\text { cooperation, } \\
\text { entrepreneurship } \\
\text { decision making }\end{array}$ & $\begin{array}{l}\text { Environmental literacy, digital literacy, } \\
\text { critical thinking, empathy, financial } \\
\text { literacy, observation, map literacy, legal } \\
\text { literacy, communication, stereotypes, and } \\
\text { prejudice, using evidence, location analysis, } \\
\text { media literacy, self-control, political } \\
\text { literacy, problem-solving, social literacy } \\
\text { participation, drawing and interpretation of } \\
\text { tables, graphics and diagrams, using } \\
\text { Turkish correctly, beautifully and } \\
\text { effectively, innovative thinking, perception } \\
\text { of time and chronology }\end{array}$ \\
\hline
\end{tabular}

Another curriculum that includes course-specific skills is the science curriculum. Skills included in this curriculum are presented under the headings of scientific process skills, life skills and engineering and design skills. The life skills included in the life skills title are listed as analytical thinking, decision making, creative thinking, entrepreneurship, communication and teamwork.

Apart from the work carried out by the Ministry of National Education, different studies are conducted to determine international common skills as a result of the globalized and standardized learning approach. One of them, and which was conducted by the OECD, "OECD FUTURE OF EDUCATION AND SKILLS 2030-OECD Learning Compass 2030". This is an important study carried out with dozens of experts including the experts from TTKB (Board of Education and Discipline), Turkey. With this study, which was initiated in 2015, some standards were tried to be determined to prepare the education systems of the countries for the future. In this study, in line with this purpose, first of all, competencies 
(knowledge, skill, attitude and values) were tried to be determined for today's students with a collaboration that lasted about two years. Secondly, to develop these competencies, an attempt was made to answer the question of how we can effectively use learning environments, in other words, curriculum. The skills determined by the study in question were classified under three headings as cognitive and metacognitive skills, social and emotional skills, and practical and physical skills.

The cognitive skills tool language included in the first of these titles consists of the use of learning strategies such as using the knowledge and numbers acquired, and reasoning. It includes verbal and non-verbal high-level thinking skills. Metacognitive skills include learning to learn and recognizing one's knowledge, skills, attitudes and values (OECD, 2018). Social and emotional skills consist of a series of individual capacities that can arise in consistent thought patterns. These skills include emotions and thoughts that enable individuals to develop their relationships at home, at school, at work and in the community as well as their own development, as well as fulfill their responsibilities. Other skills include using physical skills, physical tools, processes, and functions; applied skills are defined as the ability to manipulate materials, tools, equipment and artifacts to achieve specific results (OECD, 2018).

All of the skills listed above are among the basic skills that individuals will need throughout their lives. For this reason, the academic, social and individual achievements of individuals need to meet three of these skill types at the required rate. However, curricula mostly focus on cognitive and metacognitive skills. A study on social and emotional skills, called "OECD Study On Social and Emotional Skills", was started by OECD in 2018. This study, which is expected to shed light on the development of the social and emotional skills of the students in the participating countries, emphasized the critical importance of emotional and social skills in the learning processes. In the justification of the study, considering the results of important international studies such as PISA, PIAAC and TALIS, it was also referred to the importance and impact of social and emotional skills in terms of academic achievement and social cohesion (OECD, 2018). Accordingly, 5 main skill areas (The Big Five Domains) and a total of 16 skills related to these areas were determined and the study was carried out within the framework of these skills. With this study, it is aimed to examine the primary school curriculum developed by TTKB within the scope of these skills. Although there are many 
studies in the literature to examine the skills included in the curriculum, there are a limited number of studies on the curriculum developed in 2018 and afterward and there is only one study (Gündoğan, 2017) for the analysis of emotional and social skills. With the results obtained from this study, it is aimed to determine the functionality of the curricula in terms of gaining social and emotional skills by evaluating the education curricula within the framework of international criteria, apart from eliminating these deficiencies, which are expressed for the literature. In line with this goal, the questions sought in the study are as follows;

1. To what extent do the attainments in the Primary School Turkish Curriculum overlap with international social and emotional skills?

2. To what extent do the attainments in the Primary School Life Sciences Curriculum overlap with international social and emotional skills?

3. To what extent do the attainments in the Primary School Social Studies Curriculum overlap with international social and emotional skills?

4. To what extent do the attainments in Primary School Science Curriculum overlap with international social and emotional skills?

5. To what extent do the attainments in Primary School Mathematics Curriculum overlap with international social and emotional skills?

\section{Methodology}

\section{Research Model}

This study, in which the primary school curriculum was examined in terms of international social and emotional skills, is a sample of qualitative research and was conducted on the case study model. Qualitative research is one of the ways of generating knowledge that people develop to discover the depth of the social structures and systems that they build with their understanding of their potential, their secrets and their efforts. In the studies designed with the qualitative method, there is an effort to reach a deep perception of the event or phenomenon examined (Morgan, 1996). Case study is a qualitative research approach in which the researcher examines one or more conditions limited over time with data collection tools (observations, interviews, audiovisuals, documents, reports), and situations and thematic 
themes are defined (Creswell, 2007). In this study, primary education curricula are taken as cases and tried to be examined systematically within the scope of research questions.

\section{Data Sources}

The source of the data in the study is the primary school curricula developed by the TTKB. The curricula were accessed from the official website of TTKB. The curricula of Turkish, Life Sciences, Social Studies, Science and Mathematics courses were analyzed in the scope of the study were handled and the attainmnets of these curricula in the 1-4th grade, which were included in the scope of primary school, were examined. To avoid repetition in the study, the abbreviations of TC for the Turkish Curriculum, LSC for Life Sciences Curriculum, SSC for Social Studies Curriculum, SC for Science Curriculum, and MC for Mathematics Curriculum were used from time to time.

The ethical committee permission is not required in this study since the data were gathered through document analysis.

\section{Data Analysis}

In the study, the document analysis technique was used in the examination of the curriculum. Document analysis involves the analysis of written materials that contain information about the phenomenon or facts intended to be investigated (Yıldırım\&Şimşek,2018) In the analysis of the curricula, the international social and emotional skills determined by the OECD were considered as criteria. Skills related to the areas in which these skills are included are as follows;

1. Task performance

1.1. Belief in success

1.2. Liability

1.3. Self-regulation

1.4. Continuity

2. Emotional regulation

2.1. Stress resistance 


\subsection{Optimistic}

\subsection{Emotion control}

3. 3. Collaboration

3.1. Empathy

3.2. Confidence

3.3. Working together

4. Open-mindedness

4.1. 4.1 Creativity

4.2. 4.2 Tolerance

4.3. 4.3 Curiosity

5. Working with others

\subsection{1 Sociability}

\subsection{2 Energy}

\subsection{3 Self-ConfidencE}

6. Integrated Skills

6.1. Critical thinking

6.2. Metacognitive thinking

6.3. Self-efficacy (OECD, 2018).

In qualitative researches, instead of expressions of validity and reliability that is used in quantitative research, it would be better to talk about expressions such as credibility, the accuracy of results and competence of the researcher (Krefting, 1991). In this study, the peer debriefing method, which was suggested by the results obtained by Holloway and Wheeler, 1996, was used to provide credibility. Accordingly, the analysis results made by the researcher were sent to the curriculum development and field education specialists and asked to give their opinions. The results of the analysis have been revised according to the opinions of the experts, and presented after the necessary corrections have been made.

\section{Findings}

In this part of the study, the findings obtained by examining the primary school curriculum are presented according to the research questions. 


\section{Findings of the Turkish Curriculum}

In the Turkish curriculum developed by TTKB in 2019 , the attainments between grades 1-8 are included. In the study, a total of 235 attainments between grades 1-4, which is within the scope of primary school, were examined, and 37 of these attainments were found to coincide with international social and emotional skills. Since some of these attainments are repeated in the curriculum at different grade levels, they are included once in the list. These attainments are as follows;

- Shares what she/he wrote. (Grade 1-4) Sociability - Self Confidence

- $\quad$ Makes unprepared speeches (Grade 1-4) Sociability - Self Confidence - Creativity

- Writes poetry (Grade 3-4) Creativity-Metacognitive Thinking

- Writes narrative text (Grade 3-4) Creativity - Metacognitive Thinking

- Makes inferences about what they read (Grade 3-4) Critical Thinking-Creativity

- Participates in discussions and conversations in the classroom (Grade 4) Sociability Self-Confidence - Critical Thinking

- Evaluates the content of what they listen/watch (Grade 4) Sociability-Self ConfidenceCritical Thinking

- Makes prepared speeches (Grade 4) Sociability -Self Confidence

- Evaluates media texts (Grade 4) Sociability - Self Confidence - Critical Thinking

- Questions the reliability of information sources (Grade 4) Critical Thinking

- Expresses his/her thoughts about the events in the text he read (Grade 4) Sociability Self Confidence - Critical Thinking

- Creates sign. (Grade 4) Creativity

- Writes text suitable for the structural features of the letters (4th grade) Creativity

- Writes instructions about the process steps of a job (4th grade) Creativity Metacognitive Thinking

- Writes informative text (Grade 4) Creativity - Metacognitive Thinking

- Writes short text with imaginary elements. (4th Grade) Creativity- Metacognitive Thinking 
In the study, the explanations about the attainments in the curriculum were also taken into account in determining the attainments associated with the skills. In this way, it is aimed to clearly understand which behavior or behaviors the attainments meet. For example, for the acquisition of "Creates Sign", which is one of the attainment in the list, the students were asked to think of their signatures by using the initial letter of their names and their surnames, and the signature image to be created was left to their creativity. Since such explanations were made for the majority of the attainments in the curriculum, these explanations were used to analyze the skills accurately and completely.

Some of the attainments that overlap with social and emotional skills in TC overlap with more than one skill. For this reason, in addition to the number of acquisitions that coincide with social and emotional skills, the frequency of skills taking place in the curriculum was also determined. Also, the data prepared to see the distribution of skills on a class basis and to compare them numerically. They are presented in Table 2.

Table 2

Distribution of Social and Emotional Skills in the Turkish Curriculum According to Grade Levels

\begin{tabular}{|c|c|c|c|c|c|}
\hline Skill & $\begin{array}{l}\text { 1st Grade } \\
\text { (47 } \\
\text { Attainment) }\end{array}$ & $\begin{array}{l}\text { 2nd Grade } \\
\text { (46 } \\
\text { Attainment) }\end{array}$ & $\begin{array}{l}\text { 3rd Grade } \\
\text { (64 } \\
\text { Attainment) }\end{array}$ & $\begin{array}{l}\text { 4th Grade } \\
\text { ( } 78 \\
\text { Attainment) }\end{array}$ & $\begin{array}{l}\text { Total/ } \\
\text { 1st-4th Grades } \\
\text { (235 } \\
\text { Attainment) }\end{array}$ \\
\hline & $\mathrm{f}$ & $\mathrm{f}$ & $\mathrm{f}$ & $\mathrm{f}$ & $f$ \\
\hline Sociability & 2 & 2 & 2 & 7 & 13 \\
\hline Self Confidence & 2 & 2 & 2 & 4 & 10 \\
\hline Critical Thinking & & & 1 & 6 & 7 \\
\hline Creativity & 1 & 1 & 4 & 9 & 15 \\
\hline $\begin{array}{l}\text { Metacognitive } \\
\text { Thinking }\end{array}$ & & & 2 & 5 & 7 \\
\hline Total & 5 & 5 & 11 & 31 & 52 \\
\hline
\end{tabular}

When Table 2 is examined, it is seen that there are 5 social and emotional skills in the Turkish curriculum. Creativity and sociability are the first two skills that are frequently included in the curriculum. When the distribution of skills by grade levels is taken into consideration, there is an increase in the skills in the curriculum along with the increase in the number of skills at the 1 st and 2nd-grade levels and the increase in the 3rd and 4th-grade levels. This increase is at a significant level, especially at the 4th-grade level. The frequency 
of skills included in the 4th grade level in the curriculum (31) is higher than the first three grades; this difference is caused by the increase in creativity, sociability and critical thinking skills. Accordingly, it can be said that there are significant deficiencies in the curriculum due to the limited number of social and emotional skills however; it has reached a relatively competent structure with the advancing grade level.

\section{Findings of the Life Sciences Curriculum}

Another curriculum examined within the scope of the study is the life science curriculum. In this curriculum, a total of 148 attainments were included in the 1 st-3rd grade levels. A total of 33 of these attainments were found to coincide with international social and emotional skills. These attainments and related skills are as follows;

1st Grade Attainments

- Participates in the in-class dating activity. Sociability-Self Confidence

- Participates in the process of setting classroom rules. Sociability-Working TogetherSelf Confidence-Critical Thinking-Metacognitive thinking

- Complies with school rules Self-regulation

- Follows courtesy rules when communicating at school. Self-regulation

- Willing to work in in-school activities. Responsibility-Working Together-SociabilitySelf-Confidence-Energy

- Willing to participate and play games. Sociability- Energy-Self Confidence

- Develops positive emotions and thoughts about school. Optimism-Emotion Control

- Follows courtesy rules when communicating with family members at home. Selfregulation

- Plans what he/she can do during the day. Self-regulation

- Adheres to safety rules when communicating with people around. Self-regulation

- Realizes that he/she lives with people from different cultures in our country. Empathy

2nd Grade Attainments

- Introduces itself with different features. Sociability-Self Confidence

- Respects individual differences. Empathy 
- Participates in decision-making processes on class-related issues. Sociability-Working Together-Self Confidence-Critical Thinking

- Follows the rules of working with the group in activities held in the classroom and at the school. Responsibility, Collaboration, Sociability

- Expresses himself clearly and understandably when communicating at school. Self Confidence, Sociability

- Follows the rules of listening when communicating at school. Self Regulation

- Follows the rules while playing games with friends at school. Self Regulation

- Spends his/her money consciously at school according to his/her needs. Self-regulation

- Notices the duties and responsibilities that fall on the house. Responsibility

- Participates in family decision making processes. Sociability, Self Confidence, Working Together, Critical Thinking

- Be sensitive to people who need help in their immediate surroundings. Empathy

- implements the works he planned during the day. Self-regulation, Responsibility

- helps individuals who need help in traffic. Empathy, Responsibility

- Respects the lifestyles and habits of people of different cultures living in our country. Empathy

3rd Grade Attainments

- Recognizes their strengths and strengths. Self-regulation, Self-efficacy

- Realizes how his behavior affects himself and his friends. Empathy, Self-regulation, Critical thinking

- Understands the factors to be considered in the dating process. Self-regulation, Empathy, Tolerance, Emotion control

- Willing to participate in studies on social solidarity and solidarity at school. Responsibility, Empathy, Sociability, Energy, Working together, Self Confidence

- Expresses the demands and needs of the school in a school environment through democratic means. Sociability, Self-Regulation

- Takes care to protect the budget of himself and his family while meeting his/her wishes and needs. Self Regulation, Empathy, Responsibility

- Participates in social responsibility projects for the problems of people from different cultures living in our country. Responsibility, Energy, Empathy, Collaboration, Sociability, Self Confidence 
- Takes responsibility for protecting nature and the environment. Responsibility

As seen in the list, there are no attainments repeated in different classes, as in TC. However, the same attainment coincides with more than one skill or even 6 skills. Skills in the curriculum and related grade levels are presented in Table 3.

Table 3

Distribution of social and emotional skills in the life sciences curriculum according to grade levels

\begin{tabular}{|c|c|c|c|c|}
\hline Skill & $\begin{array}{l}\text { 1st Grade (53 } \\
\text { Attainment) }\end{array}$ & $\begin{array}{l}\text { 2nd Grade (50 } \\
\text { Attainment) }\end{array}$ & $\begin{array}{l}\text { 3rd Grade } \\
\text { (45 } \\
\text { Attainment) }\end{array}$ & $\begin{array}{l}\text { Total (148 } \\
\text { Attainment) }\end{array}$ \\
\hline & $\mathrm{f}$ & $\mathrm{f}$ & $\mathrm{f}$ & $\mathrm{f}$ \\
\hline Self Regulation & 5 & 4 & & 9 \\
\hline Sociability & 4 & 5 & 3 & 12 \\
\hline Self Confidence & 4 & 4 & 2 & 10 \\
\hline Critical Thinking & 1 & 2 & 1 & 4 \\
\hline $\begin{array}{l}\text { Metacognitive } \\
\text { Thinking }\end{array}$ & 1 & & & 1 \\
\hline Working Together & 2 & 3 & 2 & 7 \\
\hline Energy & 2 & & 2 & 4 \\
\hline Responsibility & 1 & 4 & 4 & 9 \\
\hline Optimism & 1 & & & 1 \\
\hline Emotion Control & 1 & & 1 & 2 \\
\hline Empathy & 1 & 4 & 5 & 10 \\
\hline Self-Efficacy & & & 1 & 1 \\
\hline Tolerance & & & 1 & 1 \\
\hline Total & 23 & 26 & 22 & 71 \\
\hline
\end{tabular}

As can be seen in Table 3, there are 13 social and emotional skills in the LC. It is noteworthy that while sociality, self-confidence and empathy are the top three skills; metacognitive thinking, optimism, self-efficacy and tolerance skills are included in the curriculum with only one attainment. The level with the highest frequency of skills taking place in the curriculum according to the grade levels is 2 nd grade. When the distribution of skills by grade level is considered, it is observed that this distribution varies. For example, while self-regulation skill is included at 1st and 2nd-grade levels, no attainment coincides with this skill at a 3rd-grade level. It is the same for the other skills represented by one attainment in the curriculum. According to this, it can be said that the life studies curriculum does not have a content that can be considered insufficient in terms of gaining social and emotional skills, but it requires 
some arrangements because the skills in the curriculum do not show a homogeneous distribution.

\section{Findings of the Social Studies Curriculum}

The social studies course curriculum covers the attainments that take place between the 4th and 8th grades. Among these attainments, 33 attainments at the 4th-grade level were examined and it was determined that 8 of them coincide with social and emotional skills. These attainments and related skills are presented below.

- Recognizes individual interests, needs and abilities. Self-efficacy

- Substitutes himself/herself for other individuals with different characteristics. Empathy

- Respects the different features of other individuals. Empathy

- Makes conscious choices between the two by distinguishing his wishes and needs. Selfregulation

- As a responsible individual, he displays conscious consumer behavior. Responsibility, Self-regulation

- Creates a sample budget of his/her own. Self-regulation

- Takes responsibility for the words and actions in family and school life. Self-regulation, Responsibility

- $\quad$ Respects different cultures. Empathy

The distribution of the attainments presented in the list on skill basis is given in Table 4.

Table 4

Distribution of social and emotional skills in the social sciences curriculum

\begin{tabular}{lc}
\hline Skill & 4th Grade (33 Attainment) \\
\hline & $\mathrm{f}$ \\
Self Regulation & 4 \\
Responsibility & 2 \\
Empathy & 3 \\
Self-Efficacy & 1 \\
Total & 10 \\
\hline
\end{tabular}

When Table 4 is examined, it is seen that the social and emotional skills at the 4th grade level of social studies lesson are limited by self-regulation, responsibility, empathy and self- 
efficacy skills.. and can be said to be an unwanted situation. It is not right to make a judgment for the majority or all of the curriculum, since the attainments at the 4th-grade level, which are only within the scope of primary school, of the social studies curriculum, are examined. However, it can be said that it is an unexpected situation to focus on only a few of the social and emotional skills, even at a single grade level, due to the nature of the course.

\section{Findings of the Science Curriculum}

When the attainments of the science curriculum for the 3rd and 4th grades are examined, it is determined that there are 82 attainments for these grade levels, and a total of 17 attainments coincide with social and emotional skills. These attainments and related skills are as follows.

3rd Grade Attainments

- Discusses the dangers of moving objects in daily life. Sociability, Critical Thinking, Self Confidence

- Discusses that touching, looking, tasting and smelling certain substances can harm the living body. Sociability, Critical Thinking, Self Confidence

- Takes responsibility for taking necessary security measures while working individually or in groups. Sociability, Responsibility

- Presents the observation results of a plant's life cycle. Sociability, Self Confidence

- Takes an active role in cleaning the environment in which he/she lives. Sociability, Confidence, Energy

- Designs an artificial environment. Metacognitive Thinking, Creativity

- Proposes solutions by researching to protect the natural environment. Metacognitive Thinking, Creativity

- Discusses the damages of battery wastes to the environment and what needs to be done in this regard. Sociability, Critical Thinking, Self Confidence

4th Grade Attainments

- Discusses the importance of the freshness and naturalness of nutrients for a healthy life based on research data. Sociability, Critical Thinking, Self Confidence

- Takes responsibility for reducing smoking in his/her immediate surroundings. Sociability, Critical Thinking, Self Confidence, Responsibility, Energy 
- Discusses the separation of mixtures in terms of their contribution to the national economy and efficient use of resources. Sociability, Critical Thinking, Self Confidence

- Makes designs for lighting tools that can be used in the future. Metacognitive Thinking, Creativity

- Discusses the importance of saving lighting usage in terms of family and national economy. Sociability, Critical Thinking, Self Confidence

- Produces solutions to reduce light pollution. Metacognitive Thinking, Creativity

- Produces solutions to reduce sound pollution. Metacognitive Thinking, Creativity

- Questions the cause of light pollution. Critical Thinking

- Questions the cause of sound pollution. Critical Thinking

Table 5

Distribution of social and emotional skills in the science curriculum according to grade levels

\begin{tabular}{llll}
\hline Skill & $\begin{array}{l}\text { 3rd Grade } \\
(36\end{array}$ & $\begin{array}{l}\text { 4th Grade }(46 \\
\text { Attainment })\end{array}$ & $\begin{array}{l}\text { Total/3rd-4th } \\
\text { Grades(82 } \\
\text { Attainment })\end{array}$ \\
\hline Attainment $)$ & & $\mathrm{f}$ & $\mathrm{f}$ \\
Sociability & $\mathrm{f}$ & 4 & 10 \\
Self Confidence & 6 & 4 & 8 \\
Critical Thinking & 4 & 6 & 10 \\
Creativity & 2 & 3 & 5 \\
Metacognitive & 2 & 3 & 5 \\
Thinking & & & \\
Energy & 1 & 1 & 2 \\
Responsibility & 1 & 1 & 2 \\
Total & 20 & 22 & 42 \\
\hline
\end{tabular}

As seen in Table 5, science curriculum includes 7 skills at the 3rd and 4th grades, and sociality, critical thinking and self-confidence are the prominent skills. Energy and responsibility skills are the least frequently included skills in the curriculum. Although the frequency of the skills taking place in the curriculum according to the grade levels is quite close, it can be said that the third-grade level attainments are relatively more effective in terms of gaining social and emotional skills when considering the difference between the number of attainment. In the light of these findings, it can be said the curriculum has some deficiencies in terms of skill diversity however considering that the majority of the attainments in the curriculum belonging to the cognitive field due to the content of the 
science course, it can be said that the curriculum has a more competent structure than expected in terms of meeting social and emotional skills.

\section{Findings of the Mathematics Curriculum}

In the mathematics curriculum, which is another of the primary school curriculum examined, a total of 229 attainments were included for grades 1-4. When these attainments were analyzed in terms of social and emotional skills, it was determined that no attainment overlapping these skills was included in the curriculum. It has been determined that almost all of the attainments in the curriculum are focused on the cognitive skills related to the numbers and operations, algebra, geometry and measurement, data processing and probability learning. Accordingly, although it has been stated that the values and competencies determined for the overall curriculum were taken as reference in the development of the mathematics curriculum, the absence of any of the social and emotional skills that are in line with these competencies and values is considered to be a significant deficiency in the name of the curriculum.

In the study, it is aimed to analyze the distribution of social and emotional skills in primary education curricula as a whole. Therefore, a comparative presentation of the inclusion of these skills in the curriculum was needed. Accordingly, firstly, it was tried to determine which skills are included in the curriculum and the data in question are presented in Table 6.

Table 6

Social and emotional skills in primary education curricula

\begin{tabular}{llll}
\hline TC & LSC & SSC & SC \\
\hline Self Regulation & Self Regulation & Self Regulation & Sociability \\
Sociability & Sociability & Responsibility & Trust yourself \\
Self Confidence & Self Confidence & Empathy & Critical Thinking \\
Critical Thinking & Critical Thinking & Self-Efficacy & Creativity \\
Creativity & Metacognitive Thinking & & Metacognitive \\
Metacognitive & Working Together & & Thinking \\
Thinking & Energy & & Energy \\
& Responsibility & & Responsibility \\
& Optimism & & \\
& Emotion Control & & \\
& Empathy & & \\
& Self-Efficacy & & \\
& Tolerance & & \\
&
\end{tabular}


As seen in Table 6, the curriculum that includes the most diverse skills is the life sciences curriculum, and the curriculum with the least variety of skills is the social studies curriculum. There is not a common skill that is included in all of the curricula, however, it would be correct to say that sociability, self-confidence and critical thinking skills are prominent skills in all three of the curriculum. Although there are different missing skills for each of the curriculum, it is seen that the "belief in success, stress resistance, trust and curiosity" skills are common missing skills that are not included in any of the curricula.

Finally, in the study, it was aimed to make a general evaluation by determining how many attainments of each skill in elementary school curricula were met in which curricula. Thus, in addition to the frequency of the skills included in the entire curriculum in the study, the total number of attainments in the curriculum and the number of acquisitions related to the skills are also included. These data are presented in Table 7.

Table 7

Distribution of social and emotional skills in primary education curricula

\begin{tabular}{|c|c|c|c|c|c|}
\hline Skill & $\begin{array}{l}\mathrm{TC}(235 / 37 \\
\text { Attainment }) \\
*\end{array}$ & $\begin{array}{l}\text { LSC(148/33 } \\
\text { Attainment) }\end{array}$ & $\begin{array}{l}\text { SSC } \\
\text { (33/8 } \\
\text { Attainment) }\end{array}$ & $\begin{array}{l}\text { SC } \\
\text { (82/17 } \\
\text { Attainment) }\end{array}$ & $\begin{array}{l}\text { Total (498/95 } \\
\text { Attainment) }\end{array}$ \\
\hline & $\mathrm{f}$ & $\mathrm{f}$ & $\mathrm{f}$ & $\mathrm{f}$ & $\mathrm{f}$ \\
\hline Self Regulation & & 9 & 4 & & 13 \\
\hline Sociability & 13 & 12 & & 10 & 35 \\
\hline Trust yourself & 10 & 10 & & 8 & 28 \\
\hline Critical Thinking & 7 & 4 & & 10 & 21 \\
\hline Metacognitive & 7 & 1 & & 5 & 13 \\
\hline Thinking & & & & & \\
\hline Working Together & & 7 & & & 7 \\
\hline Energy & & 4 & & 2 & 6 \\
\hline Responsibility & & 5 & 2 & 2 & 9 \\
\hline Optimism & & 1 & & & 1 \\
\hline Emotion Control & & 2 & & & 2 \\
\hline Empathy & & 10 & 3 & & 13 \\
\hline Self-Efficacy & & 1 & 1 & & 2 \\
\hline Tolerance & & 1 & & & 1 \\
\hline Creativity & 15 & & & 5 & 20 \\
\hline Total & 52 & 67 & 10 & 42 & 171 \\
\hline
\end{tabular}

* Total number of attainments in the curricula and the number of attainments that coincide with social and emotional skills

As can be seen in Table 7, although the curriculum with the least variety and frequency is $\mathrm{SSC}$, it is also the curriculum with the highest rate of attainment (33/8) meeting the social and 
emotional skills. Another remarkable finding is related to the distribution of skills. In each curriculum, different skills or skills are emphasized, and the social and emotional skills in the curricula do not show a homogeneous distribution. For example, while creativity skills are dominant in TC, LSC stands out with its social ability skill. Also, it is noteworthy that some skills were included in the curricula in a very limited number. Tolerance, optimism, selfefficacy and emotion control skills are among these skills. According to these findings in the table, it can be said that primary education curricula contain the vast majority of international social and emotional skills, however, there are not enough attainments in the curricula to gain certain skills. In other words, these skills are symbolically included in the curricula.

\section{Discussion, Conclusion and Suggestions}

In primary education, which is responsible for providing the basic knowledge, skills, behaviors and habits that all individuals in the society should have, one of the basic skills that students should acquire is social skills. Social skills help individuals, one of the important goals of education, to adapt to the society they live in (Çubukçu \& Gültekin, 2006). To gain social skills, the primary school period in which students acquire their first learning experiences is very important. Experiences to be offered to students during this period should be able to support the acquisition of these skills. This is related to the fact that the content of the curriculum, which is the main guide in the organization of learning experiences, is similarly adequate.

These skills, which are often referred to as social skills in the curriculum, were also addressed by the OECD and are expressed as "social and emotional" skills by expanding the scope of these skills. It was suggested that these skills should be included in the curriculum by underlining the increasing importance of these skills for students' cognitive and emotional development. In this study, the primary education curriculum developed in 2018 and after were examined within the scope of these skills.

In the Turkish curriculum, which is the first curriculum examined in the study, it was determined that five social and emotional skills were included; the most frequently used skill was creativity and the self-regulation skill was the least. Also, it was concluded that the most effective grade level in the acquisition of social and emotional skills is 4th grade. When 
examining the content of TC, it is noteworthy that, as in the previous curriculum, the skills specific to Turkish lessons were not included. Using Turkish correctly, effectively and beautifully, critical thinking, creative thinking, communication, problem-solving, research, using information technologies, entrepreneurship, decision making, reading between texts, importance to personal and social values are the basic skills of 2005 TC. When the specific objectives of the Turkish Lesson in 2019 TC are examined, it is stated that the language skills listed as listening/watching, speaking, reading and writing in the course should be improved with the items listed here. In the curriculum, under this heading, the skills of researching, exploring, interpreting, structuring in mind, accessing information, organizing, questioning, using and producing information are also highlighted. As can be seen, mostly cognitive skills, especially language skills, are included in TC. For this reason, it can be said that the absence of social and emotional skills is directly related to the curriculum content. However, when the basic skills specific to the course in the 2005 TC are examined, it is seen that some of these skills (critical thinking, creative thinking, communication, entrepreneurship) overlap with the skills determined by the OECD. Accordingly, it will be correct to say that 2019 TC is not a curriculum with the desired quality in terms of social and skills acquisition, and has more inadequate content than the previous curriculum.

When the studies on examining the skills in the Turkish curriculum in the literature are examined, Kayhan (2018) studied the 1st-8th grades within the scope of 21 st-century skills in the study, and concluded that only 14 attainments are related to 21 st-century skills. In his study, Öztürk (2018) examined the appropriateness of the comprehension attainments in the Turkish curriculum to basic skills and addressed critical thinking skills, creative thinking skills, problem-solving, research and decision-making skills. Accordingly, he determined that some of the attainments he examined did not match the basic facts. Altınsöz (2016) stated that the attainments were not sufficient in terms of critical thinking skills as a result of his study of the 4th-grade achievements of TC. In her study, Hezen (2009) determined that the skill that was featured most in the 2005 TC was critical thinking and the skill that was given the least was entrepreneurship. Gömleksiz and Kan (2007) determined that according to students' views 2005 TC is effective in acquiring problem-solving and decision making skills. In his study, Temizkan (2014) examined Turkish textbooks instead of curriculum and determined that these books were not sufficient to gain skills. In his study, Zevfi (2015) determined that Turkish textbooks are not sufficient in terms of reflecting basic skills and 
presenting these skills to students. Similarly, Yaşar (2013) examined the Turkish textbooks and concluded that the main skill in the books is the skill of using Turkish correctly, beautifully and effectively, critical thinking and creative thinking skills. Özatalay (2007) found that most of the Turkish textbooks do not include sufficient studies on these basic skills. When other studies on the examination of the skills in the Turkish curriculum are examined, the deficiencies for cognitive skills are highlighted in these studies (Özbay, 2012; Karadağ, 2012). As can be seen, the studies in which the Turkish curriculum and textbooks have been examined are mostly related to $2005 \mathrm{TC}$, but almost all of these studies have underlined the lack of basic skills in the curriculum and textbooks. For this reason, it is thought to be necessary to reach the aim of the course, which is stated as the "prerequisite for learning, personal and social development and vocational skills in all other fields (MEB, 2018)" in the development of TC considering the aforementioned deficiencies.

Two of the other curricula examined in the study are LSC and SSC. While LSC is the most numerous and diverse curriculum with social and emotional skills, SSC is the curriculum with the least variety of skills. However, it was concluded that the rate of involving gains related to social and emotional skills in SSC is higher than in other curricula. The curriculum for these two courses includes also course-specific skills. Among these skills, skills close to social and emotional skills (critical thinking, empathy, self-management, communication, collaboration, social participation) determined by OECD are also included. Thus, empathy and social participation skills, which are among these skills, are among the prominent skills in LSC.

The purpose of the life sciences course is stated as the child's self-knowledge, understanding the natural events around him, getting to know his social environment and developing himself in this environment (Öztürk et al., 2007). Another course that allows individuals to better understand themselves and their environment is social studies (Akaydın \& Kaya, 2015). Social studies is a primary education course (MEB, 2005) which is a continuation of the Life Science course (1st, 2nd and 3rd grades), where the concept of past, present and future is examined; aimed to make the child gain social personality; covers social sciences such as history, geography, sociology, psychology, philosophy, political science and law, and citizenship knowledge. For this reason, it is expected that the curriculum of life studies and social studies courses will complement each other and include basic skills that will help the 
individual to know and adapt to the individual, the environment and the society in which they live. Considering the results obtained in the study on the social and emotional skills included in these skills, it is seen that both of the curricula are not in the desired competence to achieve the stated goals. Although empathy and social participation were among the skills that were stated to be similar to those determined by the OECD in the curriculum, it was also noteworthy that there were significant deficiencies in other skills. Accordingly, it can be concluded that the curriculums also contain some deficiencies in terms of the skills determined by MEB. In his study, Özmutlu (2020) examined the distribution of mental abilities in SSC and stated that there are forgotten skills as well as prominent skills in the curriculum. Öğreten (2017) concluded that the content of the textbooks is at a medium level to gain the basic skills in the SSC. Hayırsever (2010) found that social studies course, teacher guide and student workbooks have some deficiencies in terms of basic skills aimed to be acquired in the social studies curriculum. Öztürk (2019) concluded that first-grade textbooks should be revised to gain basic skills in the life science lesson curriculum. Gündoğan (2017) examined LSC in terms of social skills and determined that $37 \%$ of the gains in the curriculum met social skills. Akçay and Öztürk (2017) stated that different arrangements and practices should be made to gain basic skills to students in the curriculum based on some deficiencies for LSC. In his study, Barlas (2015) stated that teachers found the LSC to be generally cultivated in acquiring common and lesson-specific skills. In his study, Narin (2007) concluded that LSC is not completely sufficient in terms of basic skills. As seen in different studies, apart from a study based on teacher opinions (Barlas, 2015), there are some deficiencies in the skill-making process of current and previous life studies and social studies lesson curricula. Accordingly, considering the adaptation of the individual to the society it is in, using social skills in their relations with other individuals (Akkök, 1996), it becomes necessary to organize the curriculum of life studies and social studies courses, which have a very close purpose, to gain these skills.

The last two curricula examined in the study are SC and MC. It was determined that critical thinking and sociability skills were the prominent skills in SC and that the most diverse skills were included within the scope of this curriculum after LSC. It is seen that there is no place in $\mathrm{MC}$ that matches social and emotional skills. As it is known, science and mathematics courses are in the category of courses called numerical courses. In these lessons, it is usual to focus mainly on cognitive skills in terms of their scope, but it would be quite an erroneous 
point of view to expect them to be developed in a completely exempt structure from social and emotional skills. Thus, when the curricula of the courses in question are examined, it is seen that the creative thinking and teamwork skills offered within the scope of life-specific life skills in SC directly coincide with the skills determined by the OECD, and through these skills, students' processes of accessing and using the information in science lessons are tried to be supported. The fact that the same point of view could not be reflected in the MC caused the curriculum to have a rather emotionally lacking structure while the cognitive aspect of the curriculum came to the fore. This makes MC a curriculum where student development is handled one way; It is an important obstacle for the achievement of the goal of "developing a positive attitude towards mathematics" which is among the objectives of the course. Considering the relationship between positive attitude towards the course and academic achievement, enriching the attainments in $\mathrm{MC}$ in terms of social and emotional skills is expected to contribute significantly to the cognitive skills expected of students. When the studies on the curricula are examined in the literature, Erduran and Kamer (2018) examined the science curriculum in terms of life skills and stated that there were significant deficiencies in it. In different studies on the analysis of skills in science education curriculum and textbooks (Yıldız and Tatar (2012), Kılıç et al. (2010), Dökme (2005), Temiz and Tan (2003)). affective domain was not taken into account by focusing on cognitive skills. Considering the studies related to MC, it was observed that in the study of Bulut (2015), it was concluded that some skills were not included in the books by examining the status of the basic skills in the primary school mathematics curriculum in the student workbooks. Apart from this, there is no study for skill analysis, but the studies that Demir and Budak (2016) and Yabaş and Altun (2010) increase self-efficacy, self-regulation, motivation, and metacognitive skills increase academic success in mathematics course, and support their results differently.

Social and emotional skills indicate the acquisition of important qualities related to the development of the person as a whole, both emotionally and academically, both in school life and out of school (Pasi, 2001). The acquisition of these skills from an early age is important for the individual to discover his/her own characteristics and competencies, to know the environment he lives in, to establish adequate and qualified relationships with the individuals in his social environment, in other words, to be able to grow up socially and emotionally. To provide all these features, the education received by the individual, apart from the environment in which he/she is and the people with whom it is in contact, also plays a 
determining role. For this reason, it should be planned to acquire the skills and competencies in this field by considering the social and emotional development of the individual as of the first moment of learning.

Including social and emotional skills in school environments helps students to exhibit positive behaviors and increase their participation in the classroom (Henningham et al., 2009). This affects not only affective states and related behaviors, but also their predisposition to learning. So much so, when teachers poorly manage the social and emotional demands teaching by curricula; students' academic achievement and behavior both suffer (Schonert, 2017). In the opposite case, curricula that support social and emotional learning also improve academic achievement and positive behavior while reducing subjective distress and conduct problems (cited by Novak and the others, 2017).

In this study, some conclusions about the curriculum, which are the basic tools for the social and emotional skills to be acquired in a formal context, have been reached. Although the expression of 2030 was used for the social and emotional skills used in the analysis of teaching skills, as seen in the results of the study, it has been underlined that these skills should be included in the curricula since 2005 . Therefore, the vast majority of these skills are not foreign and new skills for the curriculum developed by MEB. For all these reasons, it is considered that there is an important need to achieve the goal of training individuals with social competencies by moving away from the changing knowledge transfer understanding of the training curricula developed in 2018 and later, especially in the MC, and improving their social and emotional skills.

In the study, it has also been observed that studies focusing on the analysis of curricula in terms of skills focused mainly on cognitive skills. To increase the expected contribution of the results obtained in this study to the literature, it is recommended to increase the number of studies to examine different curricula in terms of various social and emotional skills.

\section{Statements of ethics and conflict of interest}

"I, as the Corresponding Author, declare and undertake that in the study titled as "Analysis of Some of the Primary Education Curricula in Terms of International Social and Emotional 
Skills", scientific, ethical and citation rules were followed; Turkish Online Journal of Qualitative Inquiry Journal Editorial Board has no responsibility for all ethical violations to be encountered, that all responsibility belongs to the author/s and that this study has not been sent to any other academic publication platform for evaluation."

\section{References}

Akaydın, B., \& Kaya, S. (2015). Türkiye'de İlkokul Hayat Bilgisi Ve Sosyal Bilgiler Alanında Yapılan Ve Ulusal İndeksli Dergilerde Yayınlanan Araştırmalara Yönelik Bir İnceleme. Mustafa Kemal Üniversitesi Sosyal Bilimler Enstitüsü Dergisi, 12(30), 251-264.

Akkök, F. (1996). Illköğretimde sosyal becerilerin geliştirilmesi (Anne-Baba El Kitabl). Ankara: MEB Yayınları

Altunsöz, D. (2016). Türkçe dersi 4. sınıf öğretim programının öğrencilerin eleştirel okuma becerilerini geliştirme açısından incelenmesi.(Unpublished Master's thesis). Graduate School of Educational Sciences, Bartın University, Bartın.

Altunbay, M. (2015). İlköğretim Türkçe dersi (6-7-8. sınıflar) öğretim programında yer alan temel becerilerin kazandırılmasında çocuk edebiyatı ürünlerinin etkisi (21. yüzyıl örneklemi). (Unpublished PHD Thesis). Graduate School of Educational Sciences, Gazi University, Ankara.

Baker - Henningham, H., Walker, S., Powell, C., \& Gardner, J. M. (2009). A pilot study of the Incredible Years Teacher Training programme and a curriculum unit on social and emotional skills in community pre-schools in Jamaica. Child: care, health and development, 35(5), 624-631.

Bal, M. (2018). Türkçe dersinin 21. yüzyıl becerileri açısından incelenmesi. Turkish Studies, 13(4), 49-64.

Barlas, B. (2015). Hayat bilgisi dersi kazanımlarının ortak ve derse özgü becerileri kazandırmadaki etkililiğinin öğretmen görüşlerine dayalı olarak belirlenmesi (Unpublished Master's thesis). Graduate School of Educational Sciences, Çanakkale 18 Mart University, Ankara.

Creswell, J. W. (2007). Qualitative inquiry\&research design: choosing among five approaches $\left(2^{\text {nd }} E d\right)$. USA: SAGE Publications. 
Çoban, O., \& Akşit, İ. (2018). Comparison of 2005 and 2017 social studies curriculum in terms of learning area, acquisition, concept, value and skill. Journal of History Culture and Art Research, 7(1), 479-505. http://dx.doi.org/10.7596/taksad.v7i1.1395

Çubukçu, Z., \& Gültekin, M. (2006). İlköğretimde öğrencilere kazandırılması gereken sosyal beceriler. Bilig, (37), 155-174.

Demir, M. K., \& Budak, H. (2016). İlkokul dördüncü sınıf öğrencilerinin öz düzenleme, motivasyon, biliş üstü becerileri ile matematik dersi başarılarının arasındaki ilişki. Dokuz Eylül Üniversitesi Buca Eğitim Fakültesi Dergisi, (41), 30-41.

Demirel, Ö. (2007). Ĕ̌itimde program geliştirme. Ankara: Pegem.

Dionnet, S. (2002). Compétences, compétences transversales et système éducatif. Evaluation de la rénovation de l'enseignement primaire, Document de travail Service de la recherche en éducation, Genève, Suisse.

Dökme, İ. (2005). Milli eğitim bakanlığı (MEB) ilköğretim 6. sınıf fen bilgisi ders kitabının bilimsel süreç becerileri yönünden değerlendirilmesi. İlköğretim Online, 4(1), 7-17.

Erduran Avci, D.,\& Kamer, D. (2018). Views of teachers regarding the life skills provided in science curriculum. Eurasian Journal of Educational Research, 77, 1-18. doi: 10.14689/ejer.2018.77.1

Eğitim Reformu Girişimi [ERG] (2012). Eğitim izleme raporu. Retrieved from https://www.egitimreformugirisimi.org/yayin/egitim-izleme-raporu-2012/.

Gömleksiz, M. N., \& Kan, A. Ü. (2007). İlköğretim 5. sınıf Türkçe dersi öğretim programının problem çözme ve karar verme becerilerini kazandırmadaki etkililik düzeyine ilişkin öğrenci görüşlerinin değerlendirilmesi. Gazi Üniversitesi Gazi Eğitim Fakültesi Dergisi, 27(3), 51-64.

Gündoğan, A. (2017). 2015 Hayat Bilgisi Öğretim Programının Sosyal Beceriler Bağlamında İncelenmesi. Bayburt Ĕ̆itim Fakültesi Dergisi, 12(23), 437-456.

Hayırsever, F. Y., \& Kisakürek, M. A. T. D. (2010). Sosyal bilgiler ders, öğretmen kılavuz ve ögrenci çalışma kitaplarının sosyal bilgiler öğretim programında kazandırılması hedeflenen temel beceriler açısından değerlendirilmesi (Unpublished $\mathrm{PhD}$ dissertation). Graduate School of Educational Sciences, Ankara University, Ankara.

Holloway, I., \& Wheeler, S. (1996). Qualitative research for nurses. Oxford: Blackwell Science Ltd.

Hezen, E. (2009). İlköğretim 1-5. sınıflar türkçe dersi öğretim programı ve kılavuzu'nun öğelerinin öğretim programı'nda yer alan temel becerileri geliştirmeye uygunluğu. 
(Unpublished master's thesis). Graduate School of Educational Sciences, Hacettepe University, Ankara.

Karadağ, Ö. (2012). Anlama becerileri açısından Türkçe dersi öğretim programı'na (6, 7, 8. sınıflar) eleştirel bir bakış. Cumhuriyet Üniversitesi Edebiyat Fakültesi Sosyal Bilimler Dergisi, 36(1), 97-110.

Kayhan, E. Sekizinci sınıf türkçe öğretim programı'nın (2018) 21. yüzyıl becerileri açısından değerlendirilmesi. Adnan Menderes Üniversitesi Eğitim Fakültesi Eğitim Bilimleri Dergisi, 10(2), 20-35.

Kılıç, G. B., Haymana, F., \& Bozyılmaz, B. (2010). İlköğretim fen ve teknoloji dersi öğretim programı'nın bilim okuryazarlığı ve bilimsel süreç becerileri açısından analizi. Eğitim ve Bilim, 33(150).52-63.

Krefting, L. (1991). Rigor in qualitative research: the assessment of trustworthiness. The American Journal of Occupational Therapy, 45 (3), 214-222.

Milli Eğitim Bakanlığı [MEB]. (2005). Türkçe dersi 1-5. sınıflar öğretim programı. Ankara: Milli Eğitim Bakanlığı Yayınları.

MEB, (2018). Hayat bilgisi dersi 1,2 ve 3. sınıflar öğretim programı Ankara: Milli Eğitim Bakanlığı Yayınları.

MEB, (2018). Matematik dersi 1-8. sinıflar öğretim programı. Ankara: Milli Eğitim Bakanlığı Yayınları.

MEB, (2018). Fen bilimleri dersi 3-8. sınıflar öğretim programı. Ankara: Milli Eğitim Bakanlığı Yayınları.

MEB, (2018). Sosyal Bilgiler dersi 4-8. sınıflar öğretim programı. Ankara: Milli Eğitim Bakanlığı Yayınları.

MEB, (2019). Türkçe dersi 1-8. sinıflar öğretim programı. Ankara: Milli Eğitim Bakanlığ1 Yayınları.

Morgan, D. L. (1996). Focus groups as qualitative research (Vol. 16). Sage publications.

Narin, D. (2007). İlköğretim hayat bilgisi dersi öğretim programı'nın vatandaşlık bilgi, beceri ve değerlerini kazandırmasına ilişkin öğretmen görüşleri. (Unpublished Master's thesis). Graduate School of Educational Sciences, Anadolu University, Eskişehir.

Novak, M., Mihić, J., Bašić, J., \& Nix, R. L. (2017). PATHS in Croatia: A school - based randomised - controlled trial of a social and emotional learning curriculum. International Journal of Psychology, 52(2), 87-95 
OECD (2018). OECD study on social and emotional skills. Retrieved from http://www.oecd.org/education/ceri/social-emotional-skills-study/.

OECD (2018). OECD future of education and skills 2030. Retrieved from https://www.oecd.org/education/2030-project/contact/.

Öğreten, A. (2017). Sosyal bilgiler dersi öğretim programındaki temel becerileri kazandırmada ilkokul dördüncü sınıf sosyal bilgiler ders kitabı içeriğinin yeterliliğine ilişkin ögretmen görüşleri. (Unpublished Master's thesis) Graduate School of Social Sciences, Ordu University, Ordu.

Özatalay, H. (2007) Illköğretim ikinci kademe Türkçe öğretim programında öğrencilere kazandırılması hedeflenen temele becerilerin Türkçe ders kitaplarında kullanılmasına ilişkin durum çalışması. (Unpublished Ph.D Thesis). Graduate School of Educational Sciences, Marmara University, İstanbul.

Özbay, M., \& Melanlioğlu, D. (2012).Türkçe öğretim programlarının dinleme becerisi bakımından değerlendirilmesi. Electronic Turkish Studies, 7(1),87-97.

Özkan, H. H. (2009). Bilgi toplumu eğitim programları. Süleyman Demirel Üniversitesi Sosyal Bilimler Enstitüsü Dergisi, 10,113-132.

Özmutlu, E. (2020). Sosyal bilgiler alanı öğretim programlarına ait kazanımların zihinsel beceriler temelinde gösterdiği dağılımın incelenmesi, Turkish Studies-Education, 15(1), 15-32. http://dx.doi.org/10.29228/TurkishStudies.40359

Öztürk, T. (2015). Öğrencilerin hayat bilgisi dersi öğretim programındaki temel becerileri kazanmalarına yönelik öğretmen görüşleri. Eğitim ve Bilim, 40(181), 271-292.

Öztürk, M. K. (2019). Birinci Sınıf Hayat Bilgisi Ders Kitabının Hayat Bilgisi Dersi Öğretim Programında Yer Alan Temel Beceriler Açısından İncelenmesi. TURAN-SAM, 11(41), 535-541.

Öztürk, C., Acun, İ., Akengin, H., Ata, B., Baysal, N., Demircioğlu, İ., Doğanay, A., Gültekin, M., Kabapınar, Y., Karabağ, G., Tekindal, S., Yanpar, T., Yaşar, Ş., \& Yel, S. (2007). Hayat bilgisi ve sosyal bilgiler ögretimi yapılandırmacı bir yaklaşım. Ankara: Pegem A Yayıncılık.

Schonert-Reichl, K. A. (2017). Social and emotional learning and teachers. The future of Children, 137-155. doi:10.1353/foc.2017.0007

Temiz, B. K., \& Tan, M. (2003). İlköğretim fen öğretiminde temel bilimsel süreç becerileri. Ë̆itim ve Bilim, 28(127), 18-24. 
Temizkan, M. (2014). Ortaokul Türkçe ders kitaplarının Türkçe dersi öğretim programındaki temel beceriler açısından incelenmesi. Ana Dili Ĕ̈itimi Dergisi, 2(1), 49-72.

Yabaş, D., \& ALTUN, S. (2009). Farklılaştııılmış öğretim tasarımının öğrencilerin özyeterlik algıları, bilişüstü becerileri ve akademik başarılarına etkisinin incelenmesi. Hacettepe Üniversitesi Eğitim Fakültesi Dergisi, 37(37), 201-214.

Yaşar, F. Ö. (2013). Ortaokul (5, 6, 7 ve 8. sınıf) Türkçe ders kitaplarının temel beceriler açısından incelenmesi. (Unpublished Ph.D thesis). Graduate School of Educational Sciences, Çanakkale 18 Mart University, Çanakkale.

Yıldız, E., \& Tatar, N. (2012). Fen ve teknoloji ders kitaplarındaki etkinliklerin bilimsel süreç becerilerine ve yapısal özelliklerine göre incelenmesi. Ĕ̌itim ve Bilim, 37(164), 108125.

Yıldırım, A., \& Şimşek, H.(2018). Sosyal bilimlerde nitel araştırma yöntemleri. Ankara: Seçkin Yayıncılık

Zevfi, R. (2015). Ortaokul Türkçe ders kitaplarının Türkçe dersi öğretim programında yer alan temel beceriler açısından incelenmesi.(Unpublished PHD Thesis). Mustafa Kemal Üniversitesi, Hatay. 